\title{
Waking Up to Memmi
}

\section{A Dwam of Critical Whiteness Studies in School Curriculum and Pedagogy}

\begin{abstract}
This critical reflective practice article juxtaposes the temporal relationship between lived experiences in my past, with my present actions as a schoolteacher. Presented in the style of a dwam-the state of semiconsciousness that precedes sleep-l uncover dominant colonial narratives that continue to inscribe racialized power relations in school curriculum and pedagogy, and that have done so throughout my experiences as a childstudent and an adult-teacher. Drawing from Albert Memmi's "colonizer who refuses," my dwam demonstrates critical awakening as a white teacher through six scenes that span four decades. KEYWORDS Autoethnography; Critical whiteness; Reflective practice; Critical praxis research; Dwam
\end{abstract}

Critical researchers in the academy have documented the replication of hegemony within Western institutions, like schools. ${ }^{1}$ This article adds to understandings of hegemony in school curriculum and pedagogy by reporting on my own critical reflective research. I approached this reflective practitioner research with the aim of deepening my understanding of the processes of imprinting colonial narratives on my consciousness, as a white child-student, and later an adult-teacher in Australian schools. ${ }^{2}$ I further wondered what research method I could apply to develop such an understanding, and then explored how I could communicate the method and my findings to an audience of schoolteacher peers.

This essay demonstrates a method of critical praxis research (CPR) that I developed, introducing the notion of dwam (or dwamming) as an epistemology to enliven representations of lived experience in critical reflective teacher research. Framing my own lived experiences of curriculum and pedagogy using Albert Memmi's The Colonizer and the Colonized, ${ }^{3}$ I find a continued cultural legacy of colonialism in Australian schools, where First Peoples' knowledges, histories, and stories are marginalized by silences and misrepresentations that

Departures in Critical Qualitative Research, Vol. 7, Number 2, pp. 72-92. ISSN 2333-9489, electronic ISSN 2333-9497. (C) 2018 by the Regents of the University of California. All rights reserved. Request permission to photocopy or reproduce article content at the University of California Press's Reprints and Permissions web page, http://www.ucpress.edu/journals.php?p=reprints. DOI: https://doi.org/ I0.1525/dcqr.2018.7.2.72. 
are embedded in the enactments of school curriculum. Further, that colonialism continues to present barriers to my critical, activist schoolteacher pursuit of hopeful futures.

I begin with a discussion of theoretical framing and research methodology that includes critical whiteness studies, autoethnography, and CPR. I provide an explanation of the notion of a dwam and identify twelve benefits of using dwam as a method to collect and analyze autoethnographic data, and to disseminate CPR. After providing a sequence of steps that I undertook in the construction of my dwam, I present my dwam as a story in six parts.

\section{CRITICAL WHITENESS STUDIES}

Critical whiteness studies rejects stable ontologies of universal truth that are epistemologically framed through white privilege. It problematizes hegemonic social, political, and economic structures, viewing those structures as Other rather than a practice of normalcy. ${ }^{4}$ Richard Delgado and Jean Stefanic connect hegemony with whiteness, observing that whites believe there is a universally valid truth, or an ideal way of knowing and being, and that this truth surpasses racialized understandings of the social world. ${ }^{5}$ Nelson Rodriguez identifies the subversive nature of whiteness as a project of domination, adding that whiteness seeks to maintain "colorless its color (and hence its values, belief systems, privileges, histories, experiences, and modes of operation) behind its constant constructions of otherness." ${ }^{6}$ bell hooks asserts that dominance results from reifying white knowledge, while those whose lived experience is represented by alternative narratives (including First Peoples' knowledges, histories, cultures, and languages) are marginalized. ' Zeus Leonardo adds, "in order for white racial hegemony to saturate everyday life, it has to be secured by a process of domination."

\section{AUTOETHNOGRAPHIC CRITICAL PRAXIS RESEARCH}

Tricia M. Kress defines CPR as a scholarly pursuit for practitioners that combines theory and practice to challenge hegemony, and that engages with stories of resistance to empower practitioners' voices. The goal of CPR is self/other/ world transformation. ${ }^{9}$ Through my self-reflective research, I have sought to destabilize what I thought I knew, disrupting my assumptions of universal truths, viewing my hitherto constructions of knowledge as privileged, identifying how this knowledge has manifested in my teacher praxis, and critically understanding how I have replicated white dominance. 
I locate my CPR within the field of autoethnography, which Carolyn Ellis defines as a form of research at the intersection of the personal and the cultural, where the autoethnographer looks inwards and outwards as both researcher and researched. ${ }^{10}$ Robin M. Boylorn and Mark P. Orbe observe that autoethnography opens possibilities for personal and cultural critique. ${ }^{11}$ Ayana Allen, Stephen D. Hancock, and Chance W. Lewis assert that autoethnography can be "intermingled with personal narrative, dialogical moments, and the rebirth of memories in real-time spaces [to give] voice to the voiceless and access to a storied life and experience." ${ }^{12}$ My research draws on reflective narratives from twenty years of experiences as a schoolteacher as data. In this article, these mystories ${ }^{13}$ inform the personal critique and are representations of my lived experiences in the cultural setting of Australian schools. I draw on Memmi's The Colonizer and the Colonized to problematize my experiences, which I then view through a lens of critical whiteness studies, and which locates the mystories within the cultural replication of dominant narratives throughout Australian school curriculum and pedagogy. I present the research as a dwam.

\section{DWAM}

The word dwam has Scottish origins and describes the state of semiconsciousness that might precede sleep. ${ }^{14}$ James A. Stevenson and Iseabail Macleod offer that a dwam is "a fit of abstraction which leaves a person affected unaware of, or indifferent to, what is going on around him." 15 My dwam begins and ends in a semiconscious state that opens me to "a fit of abstraction," wherein I become lost in self-reflective thought, and wherein Stevenson and Macleod's definition-that includes lack of awareness or indifference-becomes an overarching metaphor to describe uncritical responses to colonial narratives being inscribed in my schoolteacher praxis. The word dwam is not widely used beyond the field of Scottish literature because, like many cultural groups that are subject to political forces of colonization, the Scots' oppressors, the English, have a history of denying Scottish language, history, and culture. ${ }^{16}$ A similar phenomenon to dwam or of dwamming appears in American popular culture with the opening voiceover to The Twilight Zone:

There is a fifth dimension beyond that which is known to man. It is a dimension as vast as space and as timeless as infinity. It is the middle ground between light and shadow, between science and superstition, and it lies between the pit of man's fears and the summit of his knowledge. This is the dimension of imagination. It is an area which we call the Twilight Zone. ${ }^{17}$ 
Taking a position in "the middle ground between light and shadow," my dwamming disrupts Western epistemologies of the scientific method and privileges "the dimension of imagination" as a way of knowing. This approach to research opens my reflections on my teaching practice to new insights and enables me to generate new and critical knowledge of the impact of colonial narratives on my praxis. My application of dwam as a method of collecting and analyzing CPR data is further influenced by $a / r /$ tography and arts-based research (ABR) methods. A/r/tography and ABR empower practitioner voices in research while recognizing the potential value of creative and experimental research processes. Rita L. Irwin posits a/r/tography is research from the field of education studies that investigates spaces between art, research, and teaching, and where practice does not become subordinate to theory. ${ }^{18}$ Patricia Leavy describes the benefits of applying arts methods throughout the research process and their capacity to "expose people to new ideas, stories, or images. . . can do so in service of cultivating social critical consciousness." ${ }^{19}$ My purpose for developing dwam as a research process of data collection and analysis is to show data, rather than report on data. In doing so, I seek to democratize my research by disrupting traditional hierarchies that privilege researcher/writer interpretations of data over interpretations that you, the audience, might consider. Emerging from my CPR, I offer twelve benefits of applying dwam as research method:

I. Unsettling Western and positivist ways of knowing and understanding that reinforce hegemony by marginalizing alternative ways of knowing

2. Privileging imagination as a way of knowing

3. Disrupting linear understandings of temporal relationships to investigate possibilities that are created when the past is fused with present or future experiences

4. Reflexively acknowledging gaps in data that are drawn from memory

5. Embracing mess in data that is drawn from memory

6. Providing a platform for discourse between multiple participants including theorists, multiple representations of self, and co-performers

7. Creating synergetic knowledge by allowing theory and practice to occupy the same space, where each challenges the other, leading to deeper understandings of both

8. Crystallizing multiple truths

9. Generating critical insight into praxis 
Io. De-identifying people, places, and events by using symbol and metaphor

II. Democratizing research by opening up interpretations of data that invite the audience to take up positions in the text

I2. Democratizing research by disrupting traditional hierarchies of power that privilege researcher/writer over audience

\section{METHOD}

I have employed seven stages of data collection and analysis in my CPR. I began by recalling my experiences in places where I imagined that hegemony was inscribing colonial narratives on my consciousness. I then developed my recall of experiences into 30 mystories. The third stage of inquiry was to locate each mystory on a timeline in descending order from the present to my birth year. This led to analysis of the patterns that emerged from reading the mystories in the chronological order in which I had categorized them. As I engaged in this stage of the research, I began to shift from a central position of a "knowing I." What I thought I knew about my life story became unsettled, patterns of dominant thinking began to be revealed, I wondered how multiple voices had been marginalized in my own schooling, and I wondered about the continued impact of this on my own actions as a schoolteacher. My analysis had opened deeper understandings of my experiences as a child-student in schools, and the influence of those experiences on my current adult-teacher praxis. ${ }^{20} \mathrm{My}$ CPR located specific moments of dominant hegemony that were being both inscribed on my consciousness and replicated in my praxis.

Despite my researcher task of chronologically ordering the 30 mystories, I discovered that the processes of inscribing dominant narratives on my consciousness has not been linear. Hence, as I began the sixth stage-representing my critical self-reflection in this performative piece of writing-I sought to demonstrate my non-linear awakening by disrupting my representation of data. In the final stage, I have returned to the story and inserted two critical reflexive interludes that remind me of what Tami Spry refers to as "agency and representation." ${ }^{21}$ The first interlude reminds me that although representing my critical reflection as a dwam is a performative choice, it is a choice that reinforces my non-linear, and unfinished, critical awakening. The second interlude reminds me that I write the mystories, analyze my narratives, and write about my understandings from a position of privilege. Whatever findings emerge from this 
undertaking, I remain inscribed with(in) colonial narratives and am imbued with white privilege that remains the status quo in schools and the academy.

\section{WAKING UP TO MEMMI}

The narrative of critical awakening that I present here is fragmented, episodic, and surreal. It is a dwam organized into six scenes. The Prelude identifies some of the scholars whose contributions underpin my critical reflections. A Child Lulled to Sleep reveals the critical tension created through the process of being awakened to some of the events that established my positions of privilege. The Long Dawn of Critical Awakening locates my experiences as a critical reflective practitioner, and is followed by a second reflexive interlude. Twitching and Resisting Demons demonstrates the difficulty of maintaining my critical awakening as actions in my teaching praxis. A Leap of Hope reaffirms my commitment to unsettle dominance in my teaching praxis. Mystory of Matthias is the concluding epilogue for the dwam.

\section{Prelude}

My scotch glass is empty. Again. That's the second time tonight, but it is nearing midnight; such is the life of a critical reflective schoolteacher straddling fulltime teaching and part-time study. A neighbor's dog barks, but mine remains undisturbed in a chair next to me. In the background, late-night TV is playing one of the Godfather films.

My workspace is an arranged mess. To my left is a perilously piled compilation of books on research methods that includes Michael V. Angrosino, Arthur P. Bochner, Robin M. Boylorn, Heewon Chang, Peter Clough, Norman K. Denzin, Carolyn Ellis, Lyn Fairweather, Rita L. Irwin and Alex de Cosson, Patricia Leavy, Carl Leggo, Tricia M. Kress, and Tami Spry. ${ }^{22}$ To my right there is a scattering of books on theoretical positioning in the field of education studies that includes Paulo Friere, Henry A. Giroux, bell hooks, Gloria LadsonBillings, Zeus Leonardo, Peter McLaren, Pierre W. Orelus, and Chris Sarra. ${ }^{23}$ In front of me I am working from two books as well as tapping on the keys of my laptop. The first book, a copy of Albert Memmi's The Colonizer and the Colonized, has tagged pages and underlined passages from the section titled "The Colonizer Who Refuses." 24 The second book is my writing journal where I have drawn a timeline of my life and located 30 mystories on it. A pattern is emerging in the data, but I can't quite make it out yet.

I lean back in my chair. Back stretch. Close my eyes.

Breathe in and count. . 2..3...4. 
From the TV in the background I hear Al Pacino's voice, "Just when I think I'm out they drag me back in," ${ }^{25}$ and I smile an acknowledgement of how the Godfather's struggle mirrors my own attempts to refuse the benefits of colonialism.

\section{A Child Lulled to Sleep}

I can hear a familiar lullaby, but I can't remember the words.

The melody repeats.

My subconscious troubled, I open my eyes and look around. My reality is unsettled; my truth disrupted. My desk has gone! In fact, I'm sitting alone in what appears to be a school theatre.

A spotlight illuminates center stage. Postcolonial theorist Albert Memmi stands in the spotlight and he beckons to me. "Come," he says. The lullaby swells to a crescendo, I appear on stage with Memmi, but I have taken the form of my seven-year-old self. I'm dressed in a British colonial sailor's costume. The stage curtain begins to rise.

From the stage right wing I hear Carolyn Ellis whisper, "What we tell is always a story about the past." ${ }^{26}$

I'm facing an audience of my primary school peers. As my seven-year-old self, I am in a 2 nd grade play, and I deliver my line, "We are the sailors of the Buffalo." ${ }^{27}$ My seven-year-old self mouths a second sentence, but does not produce any sound.

From the stage left wing I hear Arthur P. Bochner console, "it's a present day realization of gaps in the story of past experience." 28 "Connect the present in which we remember and the past of which we remember." 29

"Gaps!" I hear my adult voice exclaim, "like this lullaby?"

"Yes," interrupts Memmi, "let it play out."

The familiar melody continues to repeat and from deep within my childhood memories I start to recall some of the lyrics.

\section{There's a lake in South Australia}

Little lake with lovely name. .

"Enchanting lullaby isn't it?” says Memmi, to a panel of three that has convened in the front row of the theatre, replacing my primary school peers. "Critical pedagogues, what do you think of the Other lullaby?"

"First, let's discuss the Buffalo," instructs a panelist, "this play about a boat with you as a sailor, where is the play set?" 
My seven-year-old self, in British colonial sailor costume, proudly answers that the play is set at The Old Gum Tree, ${ }^{30}$ which happens to be right next door to my school.

"Let me ask that differently. On whose traditional lands is the play set?"

Initially bewildered, but confident in his knowledge of the historical narrative, my seven-year-old self restates, "It's at The Old Gum Tree, where, on 28 December 1836, Governor Hindmarsh proclaimed the free state of South Australia in the name of King William the Fourth."

The panelist sighs, and then asks, "Can you tell us the name of the traditional owners on whose land the play is set?"

My seven-year-old self continues reciting his knowledge of the historical narrative. "There were no convicts on the Buffalo. South Australia is the only state in Australia that was established with free settlers."

The second critical pedagogue panelist interrupts. "Craig, what we want to know is, in this 2 nd grade play that reinscribes hegemonic white privilege and the dominant colonial narrative of the history of South Australia, where are the First Peoples?"

My seven-year-old self, bewildered, can't answer the question, and hums the familiar lullaby.

\section{And the story woven 'round it}

"If I might be a narrator," offers Memmi, "I think the panelists are attempting to challenge the powerful forces of colonialism in curriculum, which reify colonizer histories as universal truths, while First People's histories are omitted."

The panelists nod in agreement.

"Let me tell you then, it will be another 32 years before Craig learns the name of the Kaurnu People, the traditional owners of the land on which this vignette is taking place."

The third panelist speaks: "I think what we're seeing is the beginning of critical teacher research. Perhaps there's even liberation from the systemic professional development being done to Craig-and most of the teaching profession in the Western world - and that something rather quite meaningful is being undertaken here."

\section{Carra Barra Wirra Canna}

\section{Little star upon the lake}

"So nothing on Australia's First Peoples, but you learned about colonialism in Central America?" prompts the second critical pedagogue, "Cortez perhaps?" 
My seven-year-old self nods. "I remember the story of Cortez approaching an altar where a priest had just sacrificed someone. There was blood all over the floor."

"The violence!" exclaims the panelist, and my seven-year-old self agrees, "of European imperialism. Did you learn about the annihilation of the Aztecs by the Europeans? Did you learn about the violence and destruction of First Peoples across the Americas, or was yours the white colonial narrative of Europeans saving savages from themselves? How does this curriculum offering on Mexico relate to the history of First Peoples in Australia?"

"Where do First People's knowledges, understandings, and histories appear in your education?" adds the first panelist.

\section{Guide me through the hours of darkness}

"Right. And this lullaby?" continues the first panelist.

From the wings I hear Bochner prompt, "Memory work needs to remain cognizant of the cultural framework that the memory occurred within, and be critical of how the cultural framework between the memory and the writing will have shifted. ${ }^{31 "}$ My seven-year-old self nods. The music swells and lyrics come flooding back from my memory.

Every night the native mothers

Croon this lovely lullaby

"How very quaint," one of the panelists interrupts.

"How very exotic," offers another.

"How very Other," says the next.

"But wait," interrupts Memmi, "let it play out."

Piccaninnies' heads are nodding

Drowsy crooning fills the air

"Piccaninnies," the second critical pedagogue stands, "is that using the Merriam-Webster dictionary or the Urban dictionary?" 32

"It's the one in the song book," says my seven-year-old self. Suddenly, four other white children, all of whom I recognize as classmates despite the passing of three and half decades, appear on the stage in British colonial sailor costumes and we sing a chorus.

"Heave away/Haul away/Heave away and hear me sing/We're bound for South Australia." 33

"Another British sailor episode," says the third panelist, "A very strong theme." 
"Very patriarchal," adds the first panelist.

"Very colonial," adds the second critical pedagogue.

Memmi joins the panel, "Yes, there's plenty of the colonizer who accepts in this part."

"Not at all critical," the third panelist laments.

"It seldom is," says Memmi.

"It helps them sleep," agrees the first critical pedagogue.

Keep me safely 'til I wake $e^{34}$

\section{Reflexive Interlude I}

The scene fragments. The temperature plummets. I'm standing in Melbourne, Australia, in the middle of winter. Memmi elbows me in the ribs and then nods towards a pedestrian crossing the street. It's Stacy Holman Jones. "Go on," instructs Memmi, "ask her."

I step onto the pedestrian crossing. Traffic halts; the whole world pauses while we talk. "Hi Stacy."

"Hi Craig!" Stacy greets me with the warm, generous tone of a friend. "What an outfit!" she exclaims, noting my British colonial sailor costume.

"Yes. I'm working on a narrative inquiry, I'd love to send it to Departures in Critical Qualitative Research...”

"Oh wow. I can't wait to read it. .."

"Yeah. Only I've been working on it for months, and I'm stuck on how to (re)present my data."

"Well, what's it about?"

I explain my process of constructing 30 mystories, locating them on a timeline, and the subsequent revelation of inscriptions of whiteness on my consciousness.

"It sounds like fragmented and partial data. Have you read Eve and Christine's chapter in the Handbook of Autoethnography? They wrote a glossary in a kind of fragmented style. ${ }^{35}$ Maybe you could interrupt the piece with your reflexive researcher voice. .."

From across the street, Memmi whistles. A taxi pulls up to the pedestrian crossing. Stacy hops in and the taxi drives away. "Come," beckons Memmi.

\section{The Long Dawn of Critical Awakening}

The scene fractures again and suddenly we're back in the school theatre. We're no longer on stage. I'm no longer a child, nor am I dressed as a British 
colonial sailor. I'm standing in a corridor of what appears to be dressing room doors.

"Do you recall these doors?" Memmi asks.

"I know this door," I reply, recognizing the entrance to a classroom from my undergraduate university days. "This was my Indigenous Education class."

"Go on. You can go inside," Memmi permits, and I open the door.

A sensation of stepping back in time overwhelms me. We've stepped back to the classroom as it was in the last millennium, same decor and furnishings, same technology, same stale aroma, and same views from the windows. My lecturer, from over two decades ago, is sitting on the floor, leaning up against a wall. $\mathrm{He}$ looks exhausted. He is talking to someone, but I'm not sure who. "I just don't understand how people can be so blatant," he says. "For someone to stand up in the middle of a class and assert they don't care if I think they're racist. These people are going to be the next generation of teachers."

I step forward. "I don't either. Understand them, I mean."

My lecturer nods acknowledgement. "And then to just walk out. In the sixties we walked out if the lecturer was racist. Today it's all changed."

"We're not all racist," I offer, "I'm not."

My lecturer makes eye contact with me. Memmi quickly adds, "His is a position of principle," then turns to me and asks, "do you want to refuse the benefits of colonialism?"

"I'm not sure," I reply, suddenly feeling that my access to healthcare, housing, liberty, education, and superannuation are simultaneously being threatened.

"Ah-ha. I hear the quiver of uncertainty," says Memmi. "You're living under the sign of contradiction. You participate in and benefit from those privileges that you half-heartedly denounce. You're wondering, how you can free yourself from this halo of prestige. Come," he beckons, then turns back to my lecturer and adds, "this position of principle is not necessarily a rigid one." ${ }^{36}$

We turn around, but my path is blocked by another door that has a viewing pane of glass. I look through the glass and see that Memmi is on the other side, and he appears to be teaching. I open the door and walk through.

Memmi is mid-sentence, but he winks at me and continues, "humanitarian romanticism is looked upon in the colonies as a serious illness." 37

I raise my hand and ask, "What can we do to challenge political power? How can we challenge historical relationships?"

"Well, if you have discovered that one of the camps is injustice; then the other is that of righteousness. If you, as our colonizer, cannot rise above 
intolerable moralism which prevents you from living, if you believe so fervently that there is injustice, then let you begin by going away. Of course, to refuse colonization is one thing; to adopt the colonized and be adopted by them seems to be another; and the two are far from being connected. To be adopted by the colonized, you would have to be a moral hero. Are you some kind of a moral hero?"38

A pause engulfs the room. Eventually, I break it by replying, "Isn't this binary thinking?" My question seems to irritate Memmi.

"I don't care for that oversimplification," he says, and snaps his fingers. Everything disappears, save for another door.

The door opens. My seven-year-old self is behind it, no longer wearing the British colonial sailor costume. It's folded neatly, and he passes it to me.

"I don't want it," I say.

"Me either," my seven-year-old self says, "I want yours." I look down and notice for the first time that I'm wearing a Recognise campaign shirt. Recognise is an Australian grassroots community campaign that aims to remove racial discrimination from where it is enshrined in the Australian Constitution. ${ }^{39}$

"I'm working towards equality and liberation," ${ }^{40}$ I explain to my seven-yearold self. I'm speaking about the Recognise campaign tonight at a meeting."

Memmi responds to my seven-year-old self. "We've talked about this. One cannot change one's past, but one can (re)remember it." ${ }^{41}$

I take a piece of campaign merchandise out of my pocket. It's a Recognise keyring. "Can I give this to myself?"

"Yes," consents Memmi, "but he'll have to put the British colonial sailor costume back on. One cannot rid oneself of bigotry completely in a country where everyone is tainted by it." 42

The words are striking. Feeling alone and bewildered, I sigh and we step back through the door. The door closes, and we walk along the corridor to the final door.

The last door doesn't open, but I can see through a glass pane that it's an education symposium and the room is overcrowded with white teachers. A First Peoples presenter is standing in front of a PowerPoint presentation on Embedding Aboriginal and Torres Strait Islander Perspectives (EATSIPs) in school curriculum. $^{43}$

"Why should we privilege one culture in the curriculum?" a delegate asks.

I tap on the window. "Aboriginal and Torres Strait Islander cultures are many and diverse, and the point is we already privilege colonial narratives and..." Clearly the delegates can't hear me. 
"There's no time to be adding more to the curriculum," says another delegate.

I knock on the window. "This isn't adding, it's embedding." Still, the delegates can't hear me.

"Where can we do some professional development on this?"

I headbutt the window. "This is a conference. This is the professional development. Now go back to your school systems, your schools, your colleagues and demand your professional needs are met in sustainable. ..”

My frustration rises as I realize the delegates still can't hear me.

"This acknowledgement of traditional owners," begins a white delegate, "we do that here at the start of each semester."

I pick up a rubbish bin and hurl it into the glass pane. "Look. See that flag above the library? See the Union Jack in the top left corner? My guess is that's flying every day of the semester. So, every day, every student, every Aboriginal and Torres Strait Islander person walking on this campus sees that homage to colonialism embedded in their education. If you think one acknowledgement of traditional owners per semester is sufficient to redress continued colonial oppression, you're. .."

Memmi interrupts, “. . . invoking the end of colonization?"

I turn to Memmi. "They just can't hear, can they?"

Feeling alone, bewildered, and ineffective, we turn away. ${ }^{45}$

\section{Reflexive Interlude II}

It's the intermission of a play, and there are over 100 people crowded into the foyer of the theatre. I recognize most of the crowd as either friends, artists, research colleagues, teaching colleagues, or former students. They have been frozen in time and place as they greet one another, many holding a glass of beer or wine. I'm holding a glass of scotch, standing next to Memmi.

"Lovely glass," observes Memmi and I nod in agreement. "It's a good heavy glass. And smoky. Peaty. A strong symbol of privilege perhaps?"

"You're not making this easy, Albert," I say. "I'm trying to be critically reflexive. You're just being critical."

Memmi disagrees. "No. I think you identify systemic whiteness, but you're having difficulty confronting stories that locate you in recent personal interactions."

"Well, there are ethical constraints."

"That's an excuse. You just told a story of teachers at a conference without identifying people, the conference, or the host university. No one said 
implementing a moral determination would be easy. You have over 40 years of colonial narratives to undo, but you're worried that means undoing your accumulation of wealth. You are a property owner, are you not?"

I refuse to answer.

"Quite the dilemma then. No wonder this dwam has taken you over twelve months to write. Did you ever read the chapter in my book titled 'The Colonizer Who Accepts'?"46

"Your place amongst the colonizers who refuse is questionable too," I bite back. "Sina Salessi notes that you fail to critique the role of Western nations in propping up corrupt third world governments; Sheila Walsh cites criticism of your work that is sympathetic to Zionism; and Debra Kelly observes that your work is often constrained by binary thinking." ${ }^{47}$

Memmi snaps his fingers. We both disappear, but I feel his words resonate throughout my being, "This is your dwam of your critical whiteness."

\section{Twitching and Resisting Demons}

I reappear as my adult-teacher self, inside of the theatre, and I hear Memmi call out, "Come." I look up to the rafters of the theatre and see Memmi leaning over the rails of a catwalk, standing next to my desk with its arranged mess of books. "Come," Memmi beckons again and I am suddenly standing next to him. $\mathrm{He}$ asks, "Feeling alone, bewildered, and ineffective?"

"Well, yes," I reply.

"Wait till you see this. .."

We look back down to the stage that has become my 9 th grade classroom and my class of fourteen-year-old students are meandering towards it after attending a whole-school assembly. My seven-year-old self, wearing the British colonial sailor costume, is chatting with Matthias, a First Peoples student in my class. They appear to be classmates.

"What's a scholarship mean?" my seven-year-old self asks Matthias.

Matthias shrugs.

"But you get your uniform paid for?"

"Yeah," Matthias responds unenthusiastically.

"And they pay for your books and stuff?"

Matthias shrugs again.

"And everyone who was on stage with you, in that photo with the principal, has a scholarship?"

"Yeah"

"How come?" 
When Matthias doesn't answer, another boy in the class mockingly fills the silence. "Because they're Aboriginal students and Matthias's grandfather was from the stolen generation."

My seven-year-old self looks at Matthias, who shrugs again.

"Hey, Matthias," says a second boy, "tell us that joke about your Aboriginal uncle."

I look to Memmi. "They're not going to make him tell that joke are they?"

"You already know the joke," replies Memmi, "you knew it as a seven-yearold. It's a part of you."

"I don't want it."

"If this was a layered account, instead of a dwam, you would have to hear your seven-year-old self tell the joke. You would have to tell it yourself."

"I don't want to hear it. I don't want to tell it. Can we leave?"

"It's your dwam," says Memmi, and we begin walking through the rafters of the theatre. "But as we are walking away from the boys, consider what's worse, the language of children, or your complicit silence as a teacher. In your near present you wanted to invoke the end of colonization but now, you won't intervene and educate in a joke-telling that harms a student."

I implode.

There is no ground. No ceiling. No walls. No theatre.

I am reduced to a single atom spinning through the chaos of infinity.

\section{A Leap of Hope}

I feel my hand touch something cold and metallic.

I'm standing on a ladder. Memmi is on the other side and we're climbing. I have no sense of the ground. No ceiling. No walls. No theatre. No inside or outside.

Memmi stops us. "One must live, act and think now," ${ }^{38}$ he says, emphasizing the word now.

"I want to," I say.

"Want to what?"

"Refuse colonialism. Resist exploitation. Reject racism, it's a. .."

"Racism is a rotten plank," ${ }^{49}$ interrupts Memmi, "Yes, I've said that before. You've said that you want to refuse, resist, and reject before as well."

"I want to, I do. But you said ultimately realizing my ineffectiveness I will adopt silence rather than fight for theoretical justice."

"Theoretical justice? Is Matthias theoretical?"

"No. But you said I will exist in solitude, bewilderment, and ineffectiveness." 
"I said all of that in the I960s, before you were born. I've also said, and a lot more recently, beware of prejudice and utopias, of all dogmas. ${ }^{51}$ Come now, look down," Memmi gestures below us and I see back into the theatre's auditorium.

The three critical pedagogues have returned, and they are joined by other researchers from the field of education and teaching colleagues. In a growing sea of faces, I also recognize school uniforms and faces of students, some from my own childhood, others whom I have taught over twenty years. More students file into the auditorium. I don't recognize them, but instinctively know that these are students that I will teach in the future.

"So, what now?" I ask Memmi.

"Come," the crowd in the auditorium beckon.

"Wake up," answers Memmi, and starts shaking the ladder.

"Wake up?" I ask.

"Wake up!" he reasserts, "wake up.” The ladder is vibrating.

I blink.

My cellphone is vibrating and the alarm is calling "wake up."

I blink. I look around. My desk is back. My perilous pile of and scattering of books is back. My scotch glass is back, still empty. My dog is back, still sleeping in his chair.

I blink again as my reality resettles.

I blink again, and my eyes scan the spines of my books.

And I resolve to remain unsettled.

\section{Epilogue: Mystory of Matthias ${ }^{52}$}

I slap my cellphone into silence, then notice sunlight beginning to penetrate the venetian blinds. I'm not sure that I am awake, but I'm feeling awakened, and in the distance I can hear morning TV announcing the daily weather forecast. Preparing myself to stand and move into a new day, I notice one of the framed photos of moments in time from my teaching career. I pick it up and stare at the photo of Matthias, his Dad, and me.

Matthias's reputation preceded him. Throughout 7 th and 8 th grade, he had frequently failed to submit assignments to his teachers or even be at school on days when assessment items were due. I only taught Matthias in 9th grade Drama, and the first assignment our class had to complete was to make a puppet. With some additional guidance outside of class, I was optimistic about the progress he was making, and, on the day the project was due, Matthias handed 
in a puppet. He dropped it on my desk during the lunch break and turned to leave without saying a word.

"What's this, Matt?" I asked.

Matthias looked into my eyes, drew a long breath, restarted chewing his gum, and said, "It's my Drama thing."

"Your puppet, then?" I looked over the assignment. "You put a bowtie on him! That's nice." Unable to resist playing with a puppet, I placed my hand inside and began working out how to maneuver the head. Its googley eyes rolled about.

Matthias stood watching me play, eventually asking, "What do you reckon I'll get, Sir?"

"Can I ask you something," I interrupted his thought flow, "is this the first assessment you've done in Drama?"

Matthias answered in the affirmative with a raised eyebrow and half smile.

"I haven't got a marking sheet in front of me, but it's at least a B."

"Really!!??"

"At least a B," I confirmed. Then added, "Hey Matt, can I call your Dad?"

"What for?"

"I reckon he'd be proud of you. Come on, let me make his day."

Matthias's half smile became a full smile. "Whatever. Thanks, Sir," he said and left.

Matthias didn't continue Drama after 9 th grade and I rarely saw him. But three years later, at the school formal (prom), dressed in a tuxedo, Matthias, his Dad, and a camera approached me.

"Sir! Can we get a photo together?"

CRAIG WOOD is a PhD candidate in the Arts, Education and Law Group at Griffith University. Correspondence to: Craig Wood, Arts Education and Law, Griffith University, 176 Messines Road, Mount Gravatt, QLD 4122, Australia. Email: craig.wood@griffithuni.edu.au.

\section{NOTES}

I. See bell hooks, Writing Beyond Race: Living Theory and Practice (London: Routledge, 2013); Zeus Leonardo, Race, Whiteness, and Education (London: Routledge, 2009); Peter McLaren, Life in Schools: An Introduction to Critical Pedagogy in the Foundations of Education, 3rd ed. (New York: Longman, 1998); Pierre W. Orelus, Whitecentrism and Linguoracism Exposed: Towards the De-centering of Whiteness and Decolonization of Schools (New York: Peter Lang, 2013).

2. hooks, Writing Beyond Race, 3.

3. Albert Memmi, The Colonizer and the Colonized., trans. Howard Greenfeld (New York: The Orion Press, 1965). 
4. Leonardo, Race, Whiteness, and Education.

5. Richard Delgado and Jean Stefanic, Critical Race Theory: An Introduction, 2nd ed. (New York: New York University Press, 2012), 89-90.

6. Nelson M. Rodriguez, "Projects of Whiteness in a Critical Pedagogy," in Dismantling White Privilege: Pedagogy, Politics, and Whiteness, ed. Nelson M. Rodriguez and Leila E. Villaverde (New York: Peter Lang, 2000), I-24.

7. hooks, Writing Beyond Race, 3.

8. Zeus Leonardo, "The Color of White Supremacy: Beyond the Discourse of 'White Privilege," in Foundations of Critical Race Theory in Education, 2nd ed., ed. Edward Taylor, David Gillborn, and Gloria Ladson-Billings (London: Routledge, 2016), 265-77.

9. Tricia M. Kress, Critical Praxis Research: Breathing New Life into Research Methods for Teachers (Dordrecht, Netherlands: Springer, 201I), I 40.

Iо. Carolyn Ellis, Revision: Autoethnographic Reflections on Life and Work (Walnut Creek, CA: Left Coast Press, 2009), I3.

II. Robin M. Boylorn and Mark P. Orbe, eds., Critical Autoethnography: Intersecting Cultural Identities in Everyday Life (Walnut Creek, CA: Left Coast Press, 2014).

I2. Ayana Allen, Stephen D. Hancock, Chance W. Lewis, "The Implications of Autoethnographic Research for Access to Equity and Achievement," in Autoethnography as a Lighthouse: Illuminating Race, Research, and the Politics of Schooling, ed. Stephen D. Hancock, Ayana Allen, and Chance W. Lewis (Charlotte, NC: Information Age Publishing, 2015), 178 .

13. Norman K. Denzin, Searching for Yellowstone: Race, Gender, Family and Memory in the Postmodern West (Walnut Creek, CA: Left Coast Press, 2008).

14. Oxford Dictionary, s.v. "dwam," www.oxforddictionaries.com/definition/dwam, accessed 30 September 2016; Betty Kirkpatrick, "Useful Scots Word: Dwam," Caledonian Mercury, http://caledonianmercury.com/2010/04/1I/useful-scots-word-dwam/005243, accessed 30 September 2016.

I5. James A. C. Stevenson and Iseabail Macleodm Scoor-oot: A Dictionary of Scots Words and Phrases in Current Ese (London: Bloomsbury, 2015), 38.

16. See A. J. Aitken, "Address and Toast to the Immortal Memory of Robert Burns [1990]," in A. J. Aitken: Collected Writings on the Scots Language, ed. Caroline Macafee (1990; repr., Perth, Scotland: Scots Language Centre, 2015), http://media. scotslanguage.com/library/document/aitken/Address_and_toast_to_the_Immortal_ Memory_of_Robert_Burns.pdf, accessed 22 December 2017; Robert McColl Millar, “'Burying Alive': Unfocussed Governmental Language Policy and Scots," Language Policy 5, no. I (2006): 63-86.

17. Rod Serling, creator and narrator, The Twilight Zone: The Original Series aired 2 October 1959-19 June 1964 (New York: CBS/Viacom).

18. See Rita L. Irwin, "Becoming A/r/tography," Studies in Art Education 54, no. 3 (2013): 198-215; Rita L. Irwin and Alex de Cosson, eds., A/r/tography: Rendering Self Through Arts-Based Living Inquiry (Vancouver, Canada: Pacific Educational Press, 2004). 19. Patricia Leavy, Method Meets Art: Arts-Based Research Practice, 2nd ed. (New York: The Guilford Press, 2015), 24. 
20. Norman K. Denzin, Interpretive Autoethnography, 2nd ed. (Thousand Oaks, CA: Sage, 20I4), 38 .

21. Tami Spry, Body, Paper, Stage: Writing and Performing Autoethnography (Walnut Creek, CA: Left Coast Press, 20II), 58.

22. Michael V. Angrosino, Opportunity House: Ethnographic Stories of Mental Retardation (Walnut Creek, CA: Alta Mira Press, 1998); Arthur P. Bochner, Coming to Narrative: A Personal History of Paradigm Change in the Human Sciences (Walnut Creek, CA: Left Coast Press, 20I4); Robin M. Boylorn, Sweetwater: Black Women and Narratives of Resillience (New York: Peter Lang, 2013); Heewon Chang, Autoethnography as Method (Walnut Creek, CA: Left Coast Press, 2008); Peter Clough, Narratives and Fictions in Educational Research (Buckingham, UK: Open University Press, 2002); Denzin, Interpretive Autoethnography; Ellis, Revision; Lyn Merryfeather, You've Changed: An Evocative Autoethnography (Victoria, Canada: Friesen Press, 2016); Irwin and de Cosson, A/r/tography; Patricia Leavy, Fiction as Research Practice: Short Stories, Novellas, and Novels (Walnut Creek, CA: Left Coast Press, 2013); Carl Leggo, Sailing in a Concrete Boat: A Teacher's Journey (Rotterdam, Netherlands: Sense, 2012); Kress, Critical Praxis Research; Spry, Body, Page, Stage.

23. Paulo Freire, Pedagogy of Hope: Reliving Pedagogy of the Oppressed, trans. Robert R. Barr (New York: Continuum, 1998); Henry A. Giroux, On Critical Pedagogy (New York: Continuum, 201I); bell hooks, Teaching to Transgress: Education as the Practice of Freedom (London: Routledge, 1994); Teaching Community: A Pedagogy of Hope (London: Routledge, 2003); Gloria Ladson-Billings, The Dream-Keepers: Successful Teachers of African American Children, 2nd ed. (San Francisco: Josey-Bass, 2009); Leonardo, Race, Whiteness, and Education; McLaren, Life in Schools; Orelus, Whitecentrism and Linguoracism Exposed; Chris Sarra, Strong and Smart-Towards a Pedagogy for Emancipation: Education for First Peoples (London: Routledge, 2011). 24. Memmi, "The Colonizer Who Refuses," in The Colonizer and the Colonized, 19-44.

25. Francis Ford Coppola and Mario Puzo, The Godfather: Part II (Los Angeles: Paramount Pictures, 1974).

26. Carolyn Ellis, The Ethnographic I: A Methodological Novel About Autoethnography (Walnut Creek, CA: Alta Mira, 2004), in6.

27. The Buffalo was one of nine ships that were despatched from Britain to establish the colony of South Australia in 1836. See Bound for South Australia, "Historical Background," Bound for South Australia, 2011, http://boundforsouthaustralia.com.au/ historical-background.html, accessed 16 January 2017.

28. Bochner, Coming to Narrative, 299.

29. Arthur P. Bochner, "Notes toward an Ethics of Memory in Autoethnographic Inquiry," in Ethical Futures in Qualitative Research, ed. Norman K. Denzin, Michael D. Giardina (Walnut Creek, CA: Left Coast Press. 2007), 199 original emphasis. 30. Bound for South Australia, "Historical Background."

31. Bochner, "Notes toward an Ethics of Memory in Autoethnographic Inquiry," 200. 
32. The Merriam-Webster dictionary defines Pickaninny as "dated, now offensive-used as a term for a black child." Merriam-Webster, s.v., "pickaninny," www.merriam-webster. com/dictionary/pickaninny, accessed 30 September 2016. The Urban Dictionary defines Picaninny as "A young black person. Slightly racist." Urban Dictionary, s.v., "picaninny," http://www.urbandictionary.com/define.php?term=Picaninny, accessed 30 September 2016.

33. Bound for South Australia, "[Bound for] South Australia: The Song," Bound for South Australia, 2011, http://boundforsouthaustralia.com.au/historical-background/ bound-for-south-australia-the-song.html, accessed 16 January 2017.

34. Morva Cogan, Carra Barra Wirra Carra, song (St Leonards, Australia: Castle Music, 1965).

35. Eve Tuck and Christine Ree, "Glossary of Haunting," in Handbook of Autoethnography, ed. Stacy Holman Jones, Tony E. Adams, and Carolyn Ellis (Walnut Creek, CA: Left Coast Press, 2013), 639-58.

36. Memmi, The Colonizer and the Colonized, 64.

37. Ibid., 65 .

38. Ibid., $65-67$.

39. Patrick Dodson and Mark Leibler, co-chairs, Expert Panel on Constitutional Recognition of Indigenous Australians, Recognising Aboriginal and Torres Strait Islander Peoples in the Constitution: Report of the Expert Panel (Canberra: Commonwealth of Australia, 20I2), https://www.pmc.gov.au/sites/default/files/publications/RecognisingAboriginal-and-Torres-Strait-Islander-Peoples-in-the-constitution-report-of-the-expertpanel_o.pdf, accessed 5 August 2017; "Stand for Recognise," Recognise, www.recognise. org.au, accessed 5 August 2017.

40. Memmi, The Colonizer and the Colonized, 72.

4I. Norman K. Denzin, "Triangulation 2.0," Journal of Mixed Methods Research 6, no. 2 (2OI2): 80-88.

42. Memmi, The Colonizer and the Colonized, 67.

43. Department of Education and Training, Embedding Aboriginal and Torres Strait Islander Perspectives in Schools: A Guide for School Learning Communities (Brisbane, Australia: Queensland Government/Department of Education, 20II), http://indigenous.education.qld.gov.au/SiteCollectionDocuments/eatsips-docs/eatsips_ 20II.pdf, accessed 29 December 2014.

44. Memmi, The Colonizer and the Colonized, 84.

45. Ibid., 87 .

46. Ibid., $45-76$.

47. Sina Salessi, "The Postcolonial World and the Recourse to Myth: A Critique of Albert Memmi's Decolonization and the Decolonized," Third World Quarterly 34, no. 5 (2013): 929-4I; Sheila Walsh, "A Prophetic Voice? Albert Memmi’s Portrait du Décolonisé Arabo-Musulman et de Quelques Autres," Journal of Franco-Irish Studies 3, no. I (2013): 55-71, https://arrow.dit.ie/jofis/vol3/issi/6/; Debra Kelly, "How to Live? One Question and Six or Seven Life Lessons with Albert Memmi," Journal of French and Fracophone Philosophy 19, no. 2 (2011): 67-95, http://jffp.pitt.edu/ojs/index.php/jffp/ article/view/472. 
48. Albert Memmi, "Passport for Hoped Immortality," Journal of French and Francophone Philosophy 19, no. 2 (20II): 13-14, http://jffp.pitt.edu/ojs/index.php/jffp/ article/view/508.

49. Albert Memmi, "Racism Today: 'Us' and 'Them,"' The Unesco Courier (1986): 14-I5, http://unesdoc.unesco.org/images/0006/000694/069416eo.pdf\#nameddest $=69098$.

50. Memmi, The Colonizer and the Colonized, 87.

51. Memmi, "Passport for Hoped Immortality."

52. This co-performed mystory is a representation of a truthful experience from my teaching career. Matthias is a fictional character I have created to de-identify the person, place, and event. 